\title{
ENVIRONMENTAL MANAGEMENT IN THE ENGINEERING ENTERPRISES
}

\author{
EGOROVA, O[lga]
}

\begin{abstract}
The author of the article focuses on the engineering enterprises' management solutions aimed at ensuring ecological safety. Innovative management decisions should comply with the environmental legislation as well as follow environmental requirements. Besides, it is of essential importance to take social responsibility for the management decisions. It is also shown that it is necessary to train and control employees while managing the engineering plant in order to achieve competitive, efficient, green and innovative production.
\end{abstract}

Keywords: environmental management, engineering enterprise, lean production, corporate social responsibility

\section{INTRODUCTION}

Nowadays the environmental management at the engineering industry has become a top issue, which may affect both individual countries as well as international community. Globalization makes high demands on management resources, so it is necessary to accelerate the management development in order to improve efficiency and competitiveness. In order to make profits a lot of engineering enterprises do not pay enough attention to the environmental and social initiatives. This attitude may have a negative impact both on the environment and on the performance of the enterprise.

The aim of this paper is to research environmental management solutions at the engineering enterprises. The author's approach to environmental management analysis is based on scientific sources analysis of social and economic solutions in the engineering practice and alternative approach to environmental decision-making. The results of the research described in this paper are aimed at improving the managerial decisions at the engineering enterprises which want to achieve sustainable development. The next step of this research will be the analysis of environmental management solutions in Russia compared to Germany and preparation of the educational and consulting courses for managers, willing to improve the efficiency of the engineering production.

\section{ENVIRONMENTAL MANAGEMENT DECISIONS}

Nowadays almost every engineering company develops its production based on the anthropogenic way of development. The main features of this development type are constantly increasing volumes of non-renewable natural resources use and increased exploitation of renewable resources at the rate which exceeds the rate of natural regeneration. The present period of economic development is determined by the production intensification, increase in natural resources use and increasing biosphere pollution.

Environmental problems are also caused by management crisis. To overcome the crisis it is necessary to use qualified management resources, which take into account national traditions, mentality, values, quality and standard of living, the priorities of the country, which has a high-tech capacity. For the implementation of managerial strategies a sociological analysis of the changes in society is needed. [6]

Every enterprise has personnel which is capable of performing effective management strategies. But for a number of factors, managers' potential does not always match the complexity of the problems that need to be developed.

The main reasons for this situation are:

- unstable financial situation of many enterprises;

- enterprises' policy to appoint inexperienced specialists to top-management positions;

- low level of methodological support of the managerial staff.

Due to this situation it's important to find new approaches to environmental management issues. Firstly, traditional methods of managers' selection may not be effective to predict the performance of management, and, secondly, the results of education and training of the candidates do not always lead to desired performance of the enterprise.

In order to address environmental issues in an engineering enterprise, to achieve sustainable development the enterprise needs a new system of innovative managerial methods. The environmental management system provides solutions to environmental problems through the efficient use of available resources, social responsibility and performance assessment. Management requires competent personnel to control and direct the activities of the enterprise in order to comply with the environmental legislation.

As part of the development of innovative industries, there are two main approaches to ensure effective environmental management.

The first approach is to introduce environmental innovations in production. The introduction of 
environmental innovation - new products, new technologies, and new ways of organizing production helps to ensure sustainable development of the company.

The second approach is a qualitative change in the consciousness of management personnel. This approach justifies the Soviet and Russian scientist Moiseev: "Technological development is absolutely necessary, but it is not enough: civilization and the man should be different - needs and mentality have to be changed". [7]

Combination of these approaches may lead to efficiency increase in the production performance.

Environmental management should be seen as the prime move to the process of improvement of the enterprises' environmental performance. This leads to the fact that one of the aspects of management - is wellwritten environmental policy. Environmental policy must reflect the commitment of senior management to comply with legal, regulatory, technical and other requirements as well as the principle of continuous improvement. Environmental policy is the basis for establishing goals and objectives of the enterprise. Principles of environmental policy must be clear to all stakeholders inside and outside the enterprise. They need to be systematically evaluated and revised to ensure that environmental policy fully reflects the current situation in the enterprise.

The enterprise should establish certain environmental parameters that must be targeted at its activities, products and services. Moreover, it should monitor the compliance of the selected parameters.

Innovative management decisions may have a direct impact on improving the results of the financial, social and environmental condition of the company that is why managers have to develop new spheres of environmental performance of the engineering enterprise. These new spheres are directly related to competitiveness, quality and ecological safety of production and social development of the company as well as the engaging of the environmental activities in an automated management system. Environmental policy of the engineering enterprises defines the goals and objectives of its environmental performance, scale of the ecologization of the organizational structures of business management and commitment to environmental protection. Ultimately, compliance with these conditions determines the efficiency of environmental management.

In fact, management solutions must focus on concrete results, contributing to ecologization of the enterprises. A number of issues should be solved as well:

- Usage in all areas of resource-saving technologies;

- Artificial renewal of resources used in production with simultaneous remediation of polluted areas;

- Reduction of emissions and discharges of industrial sources of pollution;

- Increase of the degree of purification of emissions and discharges of industrial pollution sources;

- Organization of recycled or environmentally balanced utilization of industrial solid waste.[4]
While making appropriate management decisions it is essential to take into account the following requirements:

- Education and implementation of specialized management structure;

- Mandatory implementation of the existing laws and regulations in the field of ecology;

- Commitment to the environment and the interaction with the business management, related to environmental protection and safety, sanitary conditions of production conditions and the quality and safety of products;

- Public access to documentation on environmental policy for company personnel and other interested parties;

- Assessment and monitoring of compliance with environmental performance of the company's influence on the environment.

It is known that enterprises tend to choose those companies as a supplier or partner that have a positive environmental reputation. Therefore, more and more businesses are using product certification according to the standards ISO (International Organization for Standardization). ISO Certificate is a sign that the products or services of the enterprise are of high quality, and it is a guarantee of social responsibility, reliability and professional competence, company's competitiveness through the optimal use of energy and water resources, careful selection of raw materials and controlled waste processing, both on an national and international level. Respect for the environment and environmental safety are one of the most important activities in any enterprise that is why ISO certificate promotes long-term sustainable business development by reduction of the negative impacts on the nature. Moreover, certification can lower financial expenses for the environmental fines.

Environmental component of the enterprise's reputation plays an important role in its market value. Stable reputation of the enterprise, confirmed by the ISO certificates, leads to the brand popularity, thus increasing the prestige of the enterprise at the international level. If all engineering companies are certified in terms of environmental management system in accordance with international standards that would have a positive impact both on the enterprise and the environment.

Environmental management involves ensuring that all employees, whose work may significantly affect the environment, have been trained and understand what the real or potential impact of their activities on the environment is. They should have the necessary knowledge, methods and skills required to perform their tasks, as well as an understanding of the negative impacts on the environment, which their activities may cause. Each employee must know and comply with environmental legislation (within the jurisdiction), job description and be responsible for violations.

Government also plays a very important role in the framework of enterprises' environmental management. Thus it should: 
1. attract public attention to management decisions, which are related to the impact on the environment;

2. strengthen measures for managerial responsibility, which may be consequence of environmental pollution;

3. shape public environmental opinion and awareness, promoting training of management resources and professionals responsible for environmental safety in the enterprise;

4. attract businesses to raise awareness of changes in the legislation in the sphere of environmental protection, rational environmental management and sustainable development;

5. publish books on personnel and management training issues, who are responsible for making decisions in the field of environmental protection;

6. ensure the transparency of decision-making on environmental safety.

Moreover, in order to ensure environmental safety in industrial plant managers need to take environmental responsibility for the negative impact of industrial activity. Besides, in order to manage environmental problems a qualitative change in environmental policy of industrial enterprises, control of activities of the enterprise in terms of environmental legislation, involvement of all departments in proactive environmental activities and the formation of a new resource management system of values, which includes environmental values is needed.

\section{ENVIRONMENTAL MANAGEMENT IN RUSSIA}

Environmental management problems are of vital importance in Russian society. Today, special attention is drawn to engineering companies in terms of their environmental performance. One of the top managers of MMC "Norilsk Nickel" said that "socially efficient company - is a company development strategy which is aligned with the interests of its employees, territory management, and society as a whole". [8]

An example of effective management solutions aimed at achieving environmental security of the company, can be a those made by MMC "Norilsk Nickel" management, whose key objective $h$ is to reduce the harmful effects on the environment on the way to the world leadership in the industry. [3]

Since 2002 MMC "Norilsk Nickel" has been using innovative management techniques, while implementing the program "Lean Production". The essence of "Lean Production" is such management techniques, which are aimed at achieving the following objectives:

- Improvement of the technology;

- Rational use of energyand natural resources;

- Reduction of environmentally harmful waste.

Using the Norwegian experience Norilsk Nickel managers recruited a group of specialists (30 people) based on their qualifications, experience and seniority, as well as their willingness to implement environmental goals. The programmer lasted for 6 months, 11 days of which were only seminars, where specialists were taught to develop a scheme of modernization process. In the interval between the theoretical classes, students developed projects for their companies, using the experts' advice if necessary. This method allows students to master the fundamentals of a market economy, to acquire practical skills in system analysis of the processes in production chains in order to provide costeffective transfer of the enterprise to the state of maximum saving of natural resources and reducing emissions. After the programm trained professionals are able to assess possible measures to minimize waste, plan and organize work on projects in terms of "lean production" in the enterprise.

The basic principles of "Lean Production" are focused on creating strategies to prevent environmental pollution. Also, contrary to popular belief about the unprofitability of lean production, this new methodology can be profitable in terms of waste reduction. The program offers an innovative approach to solving urgent environmental and economic challenges, above all, by the employees. [5] Thus, while education the employees MMC "Norilsk Nickel" is making a significant contribution to the preservation of the environment and achieving environmental safety.

Environmental policy of engineering enterprises also includes the concept of "social responsibility". The European Commission has identified social responsibility as "a concept whereby companies integrate social and environmental concerns in their business operations and in their interaction with their stakeholders on a voluntary basis" [2] and the advisory group of experts of the International Organization for Standardization (International Standards Organization - ISO) - as a "balanced approach, in which the entities are address the economic, environmental and social issues as a way to benefit people and society as a whole". [7]

Socially responsible enterprises are any entities that identify themselves with society in which they act, and they are not only responsible for its present condition, but also for its future, including national culture, health and welfare of future generations.

The social responsibility of the enterprise in the context of environmental management - is a way of business, when the enterprise complies with the requirements of environmental legislation. This also applies to the whole transparency of the environmentally significant information. Furthermore, the enterprise should implement a number of activities aimed at reducing anthropogenic impact on the environment.

Many foreign enterprises implement corporate social responsibility policy and are already enjoying positive results. These results are mainly dealing with effective and lean production, increased competitiveness and environmentally friendly development of the enterprises as well as the society.

Analysis showing positive trends in the industrial enterprises' performance as a result of innovative corporate social responsibility measures is shown in the 
table below. These positive trends concern the effective enterprises' performance, lean and green production, innovational management methods, new system of environmentally friendly values of the enterprises' employees and positive prospective.

\begin{tabular}{|l|c|c|c|c|c|c|}
\hline & USA & Australia & India & China & Canada & Brazil \\
\cline { 2 - 6 } & $(\mathrm{n}=309)$ & $(\mathrm{n}=214)$ & $(\mathrm{n}=134)$ & $(\mathrm{n}=82)$ & $(\mathrm{n}=844)$ & $(\mathrm{n}=135)$ \\
\hline $\begin{array}{l}\text { 1. The } \\
\text { enterprises' } \\
\text { image } \\
\text { improvement }\end{array}$ & $74 \%$ & $65 \%$ & $67 \%$ & $67 \%$ & $76 \%$ & $81 \%$ \\
\hline $\begin{array}{l}\text { 2.Psychologica } \\
\begin{array}{l}\text { latmosphere } \\
\text { improvement } \\
\text { among the } \\
\text { employees }\end{array}\end{array}$ & $61 \%$ & $63 \%$ & $58 \%$ & $26 \%$ & $50 \%$ & $68 \%$ \\
\hline $\begin{array}{l}3 . \\
\text { Organization } \\
\text { loyalty } \\
\text { improvement }\end{array}$ & $48 \%$ & $44 \%$ & $43 \%$ & $28 \%$ & $41 \%$ & $59 \%$ \\
\hline $\begin{array}{l}4 . \text { Consumer } \\
\text { confidence } \\
\text { index increase }\end{array}$ & $45 \%$ & $36 \%$ & $40 \%$ & $51 \%$ & $45 \%$ & $60 \%$ \\
\hline $\begin{array}{l}\text { 5. Enterprises } \\
\text { ranking } \\
\text { improvement }\end{array}$ & $42 \%$ & $44 \%$ & $56 \%$ & $61 \%$ & $41 \%$ & $66 \%$ \\
\hline $\begin{array}{l}\text { 6. Enterprises } \\
\text { ranking } \\
\text { improvement } \\
\text { in the } \\
\text { employers } \\
\text { ranking }\end{array}$ & $39 \%$ & $38 \%$ & $35 \%$ & $37 \%$ & $44 \%$ & $59 \%$ \\
\hline $\begin{array}{l}7 . \text { Term of } \\
\text { office increase }\end{array}$ & $24 \%$ & $24 \%$ & $16 \%$ & $12 \%$ & $29 \%$ & $23 \%$ \\
\hline $\begin{array}{l}8 . \text { Top } \\
\text { managers } \\
\text { ration increase }\end{array}$ & $19 \%$ & $18 \%$ & $18 \%$ & $17 \%$ & $25 \%$ & $25 \%$ \\
\hline $\begin{array}{l}9 . \text { Competitive } \\
\text { advantage }\end{array}$ & $17 \%$ & $15 \%$ & $22 \%$ & $13 \%$ & $17 \%$ & $19 \%$ \\
\hline $\begin{array}{l}10 . \text { Workforce } \\
\text { productivity } \\
\text { improvement }\end{array}$ & $15 \%$ & $10 \%$ & $7 \% \%$ & $26 \%$ \\
\hline $\begin{array}{l}11 . \text { Positive } \\
\text { financial } \\
\text { results }\end{array}$ & $15 \%$ & $8 \%$ & $15 \%$ & & \\
\hline
\end{tabular}

$\mathrm{n}$ - number of respondents

Tab. 1. Results of the policy of corporate social responsibility

The survey results among the countries show that the policy of corporate social responsibility has positive results in all areas. However, in Russia only large international industrial enterprises and their divisions are involved in the issues of social and environmental responsibility. They strive for the development of individual and common approaches to social and environmental responsibility. The reasons for this situation are ethical and social requirements to suppliers and contractors that require the implementation of the relevant legislation, international standards and certification of "socially responsible" companies. However, small and medium enterprises are starting to implement programs of social and environmental responsibility. These changes may positively affect public consciousness of social values, which are based on human life, favorable natural and social conditions, environment and human rational relationship between society and the environment.

\section{CONCLUSION}

Environmental management as a way to protect environment is an important aspect of engineering enterprises. Therefore, managers should take environmental responsibility for the negative impact of industrial activity. Social and ethical feature of environmental management is to harmonize the interests of producers, consumers, communities and the environment. Dealing with management problems requires monitoring of production activities within the framework of environmental legislation, the involvement of all departments in proactive environmental activities and the formation of a new resource management system of values, which includes environmental values.

Adoption of innovative management solutions for the preservation of the environment is also an important aspect of the engineering enterprises, both in Russia and abroad. Therefore, in terms of innovative development engineering enterprises should take environmental responsibility for the negative impact of industrial activity. Management decisions must comply with the legislation and environmental requirements. In particular, ISO certification is one of the key issues. Finally, while managing environmental safety one should also consider all environmental aspects of business in order to achieve innovative, energy-efficient, competitive and environmentally friendly production.

\section{REFERENCES}

[1] Biltgein, F. (2004). Social responsibility of the enterprises. Luxembourg view. Ragz, Moscow

Билтгейн, Ф. (2004). Сочиальная ответственность предприятий. Взгляд из Люксембурга. Изд-во РАГС, Москва

[2] Egorova, O.S. (2011). Environmental safety issues in the context of industrial development of enterprises in Russia. Engineering technology, 2011, 65-69

Егорова, О.С. (2011). Вопросы управления экологической безопасностью в условиях инновационного развития промышленных предприятий России. Технология машиностроения, 2011, 65-69 Egorova, O.S. (2011). Management resources formation for innovative production development. MGTU ,Stankin“ bulletin. 2011, 138-141 Егорова, О.С. (2011). Формирование управленческого ресурса для развития инновационных производств. Вестник МГТУ «Станкин», 2011. 138-141

[3] Kalayda, E.V. (2004). Million economy from the "lean production". Production ecology, No.2, 2004.

Калайда, Е.В. (2004) Миллионная экономия от "чистого производства". Экология производства, № 2, 2004

[4] Klementiev, D.S.; Ribakova, M.B. (2007). Sociology of management. Sociological research, Vol.5, 2007, 153-154

Клементьев, Д.С.; Рыбакова М.В. (2007). Социология управления. Сочиологические исследования. №5, 2007, 153154

[5] Leonard, A., McAdam R. (2003). Corporate social responsibility. Quality Progress, 2003

[6] Moiseev, N.N. (2000). Civilization's destiny. The way of intellect. Languages of Russian Culture, Moscow

Моисеев, Н.Н. (2000). Судьба цивилизации. Путь разума. Языки русской культуры, Москва

Ruth, C. (2004). Corporate social responsibility: aim and method. Eurasian metalls. No.6, 2004 Рут, C. (2004). Корпоративная социальная ответственность: и цель, и средство. Металлы Евразии. № 6, 2004 